\title{
Full-length genome sequencing of the mild strain of Tomato yellow leaf curl virus in Venezuela reveals a third introduction event of this virus in New World
}

\author{
G. Romay • D. T. Chirinos • F. Geraud-Pouey $•$ A. Gillis
}

Received: 12 October 2013 / Accepted: 16 January 2014 / Published online: 6 February 2014

(C) Australasian Plant Pathology Society Inc. 2014

\begin{abstract}
Tomato yellow leaf curl virus (TYLCV) is an important monopartite begomovirus originating from the Old World. In the New World (NW), two different introductions of TYLCV had been proposed, both related to the Israeli strain (TYLCV-IL). In this study, the full-length sequencing of a Venezuelan TYLCV isolate showed $>97 \%$ nucleotide identity with the mild strain, referred as TYLCV-Mld. Therefore, our results suggest a third introduction of this virus in the NW.
\end{abstract}

Keywords Begomovirus $\cdot$ RCA $\cdot$ Viral strain $\cdot$ TYLCV introduction

Tomato yellow leaf curl disease (TYLCD) is one of the major devastating diseases throughout the world. At least six begomovirus species (family Geminiviridae), including Tomato yellow leaf curl virus (TYLCV), are associated with TYLCD (Lefeuvre et al. 2010). In the New World (NW), TYLCV was firstly reported in Dominican Republic (Polston et al. 1994) and rapidly spread in the Caribbean with devastating consequences in tomato crops. In South America,

\section{G. Romay $(\bowtie)$}

Fundación Instituto de Estudios Avanzados (IDEA), Carretera Nacional Hoyo de la Puerta-Baruta, Sartenejas, Caracas 1080, Venezuela

e-mail: gromay@idea.gob.ve

D. T. Chirinos $\cdot$ F. Geraud-Pouey

Facultad de Agronomía, Unidad Técnica Fitosanitaria, La Universidad del Zulia (LUZ), Maracaibo 4005, Estado Zulia, Venezuela

\section{A. Gillis}

Laboratory of Food and Environmental Microbiology, Earth and Life Institute, Université catholique de Louvain, Croix du Sud 2, Box L7.05.12, 1348 Louvain-la-Neuve, Belgium
TYLCV has only been reported in Venezuela, in 2007 (Zambrano et al. 2007). Nevertheless, strain determination of the virus was not possible due to the use of partial genome sequencing for diagnostic purposes, leaving unresolved the question whether the Venezuelan TYLCV isolate was introduced from the Caribbean or via another independent introduction from the Old World (OW). Therefore, whole genome amplification and sequencing of a Venezuelan TYLCV isolate was conducted in this study. Four tomato plants exhibiting TYLCV-like symptoms (reduction, yellowing and upward curling of leaves) were sampled in a tomato field from Zulia state for further analyses.

DNA extraction was performed as reported by Gilbertson et al. (1991) and TYLCV infection was confirmed in three out of four samples using specific primers that amplify the complete nucleotide sequence of capsid protein gene (Ling et al. 2006). The complete genome amplification of a TYLCV isolate Zu1-09 was obtained by Rolling Circle Amplification (RCA) using the TempliPhi Kit (GE Healthcare, Germany) according to the manufacturer's protocol. RCA product was digested with BamHI, inserted in BamHI-digested pBluescript II (SK+) (Stratagene, Netherlands) and cloned into Escherichia coli DH5 $\alpha$ cells. Recombinant plasmids carrying the full TYLCV genome were selected and subsequently sequenced by primer walking (Macrogen, South Korea). The nucleotide sequence of isolate Zu1-09 (GenBankAccession No.KF477277) was compared with TYLCV isolates available in the GenBank database. Sequence alignments and phylogenetic analyses were performed using Mega5 (Tamura et al. 2011).

Sequence analysis revealed that the complete genome size of isolate Zu1-09 comprises 2,791 nucleotides and was most closely related to isolate TYLCV-Mld [Spain7297] (GenBankAccession No. AF071228) with $98.9 \%$ of nucleotide identity. Furthermore, isolate Zu1-09 shared only 91.3-92.5\% nucleotide identity with TYLCV-IL isolates. 
Fig. 1 Phylogenetic analysis based on Neighbour-Joining tree showing genetic relationships between 39 isolates of Tomato yellow leaf curl virus worldwide. Venezuelan isolate is highlighted in bold. Tomato yellow leaf curl China virus (TYLCCNV) was added as outgroup. Numbers associated with nodes represent the percentage of 500 bootstrap iterations supporting the nodes. For each isolate, country of origin and GenBank accession number were included

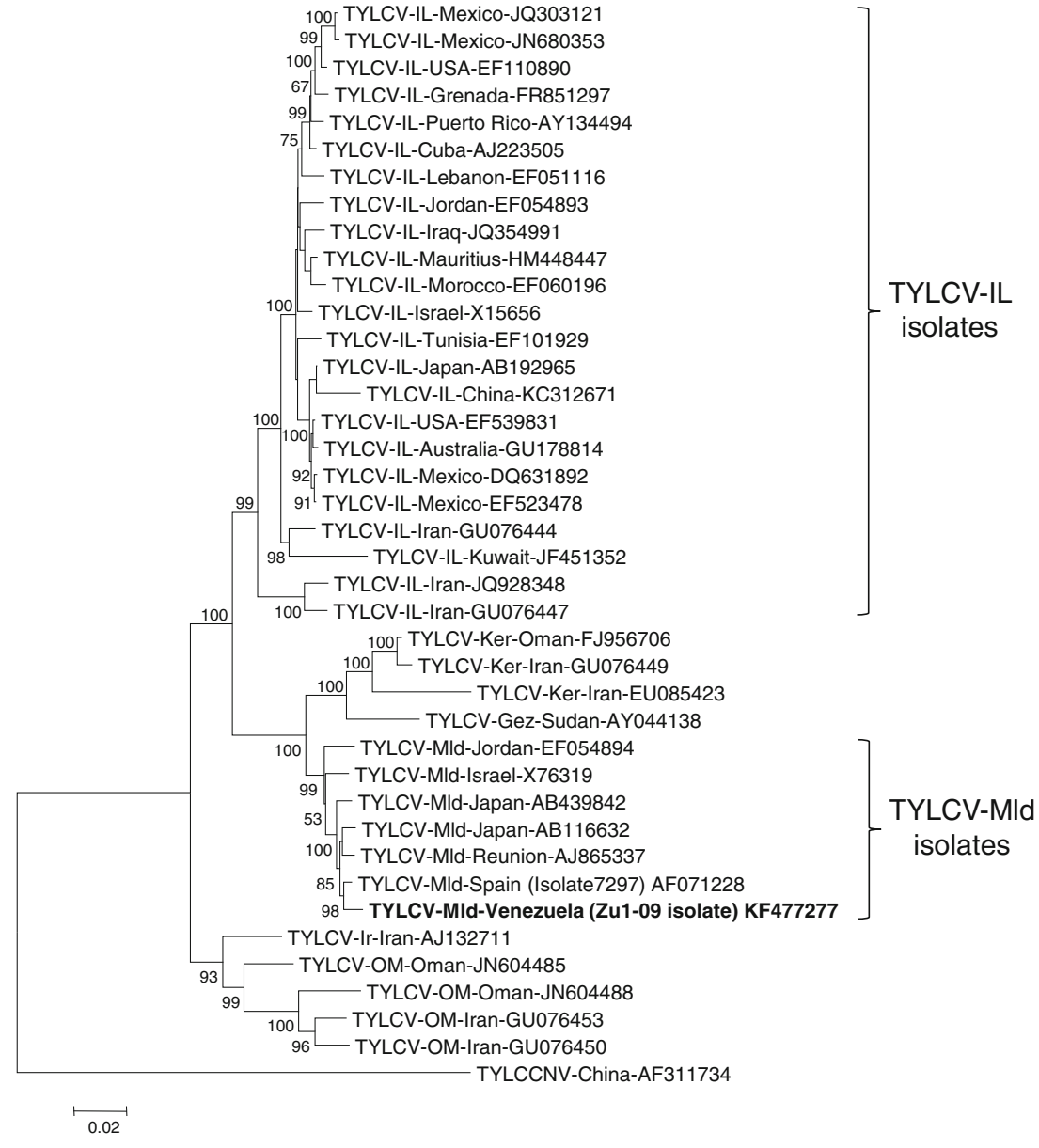

According to geminivirus strain demarcation, viral isolates sharing more than $94 \%$ are considered variants of the same strain in a geminivirus species (Fauquet et al. 2008). Thus, isolate Zu1-09 is a variant of the strain TYLCV-Mld. Phylogenetic analysis grouped isolate Zu1-09 along with other isolates of TYLCVMld strain in the same phylogenetic subcluster, whereas the rest of the American isolates were included in the TYLCV-IL group (Fig. 1). In previous phylogenetic studies, two different introductions of TYLCV in the NW have been inferred: one from Europe and another from Asia (Duffy and Holmes 2007; Lefeuvre et al. 2010). However, both events were associated with the TYLCVIL strain. Given that Venezuelan isolate Zu1-09 belongs to TYLCV-Mld strain, our results strongly suggest that at least three independent introductions of TYLCV have occurred in the NW. To our knowledge, this is the first complete genome characterization of an isolate of the TYLCV-Mld strain infecting tomato plants in the NW. The introduction of TYLCV-Mld in a remote agroecosystem of Reunion Island has resulted in severe economic losses in tomato-growing areas and provided opportunities for molecular evolution of this virus (Péréfarres et al. 2012). Moreover, strains of TYLCV are known to be involved in displacement and recombination events with native begomovirus (Monci et al. 2002; Davino et al. 2006). Further studies are needed to determine the current impact and spread of TYLCV in Venezuela and whether other TYLCV strains may be present.

\section{References}

Davino S, Napoli C, Davino M, Accotto GP (2006) Spread of tomato yellow leaf curl virus in Sicily: partial displacement of another geminivirus originally present. Eur J Plant Pathol 114:293-299

Duffy S, Holmes EC (2007) Multiple introductions of the Old World begomovirus Tomato yellow leaf curl virus into the New World. Appl Environ Microbiol 73:7114-7117

Fauquet CM, Briddon RW, Brown JK, Moriones E, Stanley J, Zerbini M, Zhou X (2008) Geminivirus strain demarcation and nomenclature. Arch Virol 153:783-821

Gilbertson RL, Rojas MR, Russell DR, Maxwell DP (1991) Use of the asymmetric polymerase chain reaction and DNA sequencing to determine genetic variability of bean golden mosaic geminivirus in the Dominican Republic. J Gen Virol 72:2843-2848

Lefeuvre P, Martin DP, Harkins G, Lemey P, Gray AJA, Meredith S, Lakay F, Monjane A, Lett JM, Varsani A, Heydarnejad J (2010) The spread of Tomato yellow leaf curl virus from the Middle East to the world. PLoS Pathog 6:e1001164

Ling K, Simmons AM, Hassell RL, Keinath AP, Polston JE (2006) First report of Tomato yellow leaf curl virus in South Carolina. Plant Dis 90:379 
Monci F, Sanchez-Campos S, Navas-Castillo J, Moriones E (2002) A natural recombinant between the geminiviruses Tomato yellow leaf curl Sardinia virus and Tomato yellow leaf curl virus exhibits a novel pathogenic phenotype and is becoming prevalent in Spanish populations. Virology 303: $317-326$

Péréfarres F, Thierry M, Becker N, Lefeuvre P, Reynaud B, Delatte H, Lett JM (2012) Biological invasions of geminiviruses: case study of TYLCV and Bemisia tabaci in Reunion Island. Viruses 4: $3665-3688$
Polston JE, Bois D, Serra CA, Concepción S (1994) First report of a tomato yellow leaf curl-like geminivirus from tomato in the Western Hemisphere. Plant Dis 78:831

Tamura K, Peterson D, Peterson N, Stecher G, Nei M, Kumar S (2011) MEGA5: molecular evolutionary genetics analysis using maximum likelihood, evolutionary distance, and maximum parsimony methods. Mol Biol Evol 28:2731-2739

Zambrano K, Carballo O, Geraud F, Chirinos D, Fernández C, Marys E (2007) First report of Tomato yellow leaf curl virus in Venezuela. Plant Dis 91:768 